\title{
Academic Motivation And Approaches To Learning In Predicting College Students' Academic Achievement: Findings From Turkish And US Samples
}

Barış Çetin, Ph.D. Canakkale 18 Mart University, Turkey

\begin{abstract}
The aim of this study is to determine if approaches to learning and academic motivation together predict grade point averages (GPAs) of students who study at Primary School Education and Preschool Education in Turkey and of students who study at Early Childhood Education in the US. The first group of participants included 166 third-and fourth-year students at Georgia Southern University's Early Childhood Education Department during the 2014 spring semester. The second group of participants included 455 third- and fourth-year students who study at Canakkale 18 Mart University's Primary School Education and Preschool Education Departments during the 2013 spring semester. It was found that approaches to learning and academic motivation together did not predict GPA of students who studied in Turkey or the US.
\end{abstract}

Keywords: Early Child Education; Approaches To Learning; Academic Motivation; GPA

\section{INTRODUCTION}

\section{Approaches To Learning}

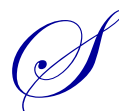

tudy of Marton and Säljö (1976), which investigated deep and surface approaches to learning, served as a starting point for this research. An important function of education is to direct students to take a deep approach and to prevent the use of surface approach (Biggs, 1999a). In an ideal system, it is expected that all students deal with the problem at hand in the most appropriate way by engaging in learning activities at the highest level or solve the problem at hand. Students who take surface approach use lower-level verbs. The presence of the surface approach indicates that something is dysfunctional in the methods of education or assessment (Biggs, Kember, \& Leung, 2001).

Biggs (1999b) found that students took a deep approach to learning main topics regardless of education methods. The deep approach can be defined as a combination of intention and process. The deep approach emphasizes understanding learning processes and is clearly different from organizing effort and concentration related studying strategies (Entwistle \& McCune, 2004). The majority of previous studies on student learning considered high quality learning in terms of the deep approach, which results in conceptual understanding (Entwistle, 2005). The deep approach is directed by the need to complete a task in an appropriate and meaningful way, which leads to using the most appropriate cognitive functions for working on a task. The use of the deep approach creates positive feelings such as interest, sense of importance, challenge, and exhilaration. On the other hand, the surface approach is related to the intention of finishing a task without putting much effort into it and seeming to fulfill requirements, leading to the use of lower cognitive activities even if the task requires higher-level activities. The surface approach is not only seen in learning but also in many other areas such as teaching or doing business. The surface approach can be expressed by the common idioms "cutting corners" or "sweepingunder the carpet" (Biggs, 1999a). 
Students who take a deep approach would not have the intention of finding shortcuts for dealing with a task. Instead, they try to find meaning in the taught material and learn in the most wanted way (Biggs, 2012). The deep approach occurs in accordance with the students' intention. In the surface approach, students try to guess what their teachers would expect from them in examinations and search for expected questions within the taught material. Students who take a deep approach handle a task with the intention of learning the material for themselves, which in turn enables them to comprehend the meaning of the taught material (Entwistle, 2009). When the surface approach is adopted, the learners focus on the surface characteristics of a situation, the wording of a text, the proposed argument, figures in a problem, and the formulas for solving a problem (Bowden \& Marton, 1998).

While the surface approach requires routine memorization, the deep approach involves making connections with previous knowledge and reasoning. The essence of the surface approach is that it relies on the use of rote learning, which derives from the intention to reproduce the material presented by the teacher in a routine way and without thinking (Entwistle \& Smith, 2002). Neither the surface nor the deep approaches to teaching are related to the personality characteristics of a teacher; thought processes are reactions to the teaching environment. Using the deep approach and avoiding the surface approach forms the basis of high quality teaching; however, many traditional methods have the opposite effect (Biggs, 1999a). The most important distinction between two approaches is that surface approach focuses on "the sign," whereas deep approach focuses on "the signified." (Marton \& Booth, 2009 , p. 22). The deep approach was associated with comprehending the author's message, while surface approach involved misunderstanding or missing the message (Marton \& Booth, 2009).

\section{Academic Motivation}

Motivation theories are founded on assumptions about human nature (Deci \& Ryan, 1985). Deci and Ryan (2002) separated motivation into three categories: amotivation, extrinsic motivation, and intrinsic motivation (Deci \& Ryan, 2002). Amotivation is strongly and negatively related to educational outcomes (Vallerand \& Bissonnette, 1992). Amotivation involves not having a motive to act (Williams \& Deci, 1996). Amotivation takes the lack of motivation and the observation of the individual's inability to sense the conditions between his or her actions and consequences as reference (Ratelle, Guay, Vallerand, Larose, \& Sene'cal, 2007). Amotivation occurs when individual students cannot get positive feedback regarding their performance or believe that they have failed on a repetitive basis. According to the revised theory of helplessness, noncontingent environments lead to amotivation. Amotivation results when one perceives oneself as incompetent to reach intended outcomes (Deci \& Ryan, 1985).

Intrinsic motivation is a source that is central to the nature of the organism. Intrinsic motivation depends on the innate need for competence and self-determination. It provides the fuel for various behaviors and psychological processes. Intrinsic needs are different from primary drives because they are not based in deficits and they do not function cyclically. However, both of them are innate and provide an energy source for behavior. In addition, intrinsic motivation can increase or decrease the intensity of drives and also influence the way one satisfies one's drives (Deci \& Ryan, 1985).

Extrinsic motivation is separated into four categories four as external regulation, introjected regulation, identified motivation and integrated regulation (Deci \& Ryan, 2002). External regulation occurs when the behavior is formed externally (Vallerand \& Bissonnette, 1992). External regulation occurs when students relate results in order to control for the function of time and rewards they attribute to learned activities (Zimmerman, 2012). The least autonomous type of extrinsic motivation is external regulation, which involves being motivated to obtain rewards or avoid punishments. External regulation has an external perceived locus of causality (Skinner, 1953, as cited by Deci \& Ryan, 2002). Introjected regulation refers to an internalized external regulation but which is not truly accepted as one's own. It is some form of partially internalized extrinsic motivation. Introjection is a type of internalized regulation and is very controlling. Introjection-based behaviors are performed in order to avoid guilt or to produce ego enhancements and feelings of worthiness. This type of regulation depends on contingent self-esteem (Deci\& Ryan, 1995, as cited in Deci \&Ryan, 2002). Regulation through identification is a more self-determined form of extrinsic motivation, because it includes valuing of a behavioral goal or regulation. Identification is important in transforming external regulation into true self-regulation. Identification seems to have an internal perceived locus of causality (Deci, \& Ryan, 2002). Identification is the process of specification of an activity by its 
value and the way an acceptable regulation of one's dynamism is taken as reference (Vansteenkiste, Lens, \& Deci, 2006).

Integrated regulation is the basis for the most autonomous form of extrinsically motivated behavior. Integrated regulation results when identifications have been assessed and brought into congruence with the personally endorsed values, goals, and needs that are part of the self. Previous studies showed that integrated extrinsically motivated behaviors are associated with more positive experiences than the less fully internalized forms of extrinsic motivation. Integrated extrinsic motivation and intrinsic motivation have many similarities (Deci \& Ryan, 2002).

Self-determination theory is a concept included in intrinsic motivation. Self -determination theory takes the experience of freedom inside one's commencing behavior as reference. The pressure caused by the condition of strengthening and any other pressure is decisive on one's actions. Self-determination often includes results or one's environmental control and choices (Deci \& Ryan, 1985). Self-determination theory takes personal growth, selfarrangement, global psychological needs, purpose of living, longings, energy and validity, unaware periods, cultural relations for motivation and effects of motivation on social environments as reference (Deci \& Ryan, 2008). Selfdetermination theory offers relatively more autonomy supplying social content or enriches internal motivation (Vansteenkiste, et al., 2006).

\section{PURPOSE}

The purpose of this study was to determine if approaches to learning and academic motivation together predict GPA in students who study at Primary School Education and Preschool Education in Turkey and in students who study at Early Childhood Education in the US.

\section{METHODS}

The model of this study was a prediction study because the aim was to determine predictive relationships of academic motivation and approaches to learning together to GPA for the students studying Preschool Education and at Primary School Education (Gay, Mills, \& Airasian, 2009).

\section{Participants}

The first group of participants included 166 (158 female and 8 male; 86 juniors and 80 seniors) third- and fourth-year students who studied at Georgia Southern University's Early Childhood Education Department during the 2014 spring semester. The second group of participants included 455 (365 female and 90 male; 220 juniors and 235 seniors) third- and fourth-year students who studied at Canakkale 18 Mart University's Primary School and Preschool Education Department during the 2013 spring semester.

\section{Materials}

Data were collected from the students who studied in the US using the Revised Two-Factor Study Process Questionnaire (R-SPQ-2F), which was revised by Biggs et al. (2001), a personal information form, and the Academic Motivation Scale developed by Vallerand et al. (1992). Data were also collected from the students who studied in Turkey using the R-SPQ-2F, which was adapted to Turkish by Y1lmaz (2009), and the Academic Motivation Scale, which was adapted to Turkish by Eymur and Geban (2011).

\section{Academic Motivation Scale}

In this study, the scale that was arranged by in Turkish Eymur and Geban (2011) and developed by Vallerand and others (1992) was used. The scale includes 28 items and 7 factors, each factor includes 4 items, and each item has 7 response categories. The scale consists of 3 intrinsic motivation factors, 3 extrinsic motivation factors, and one factor of amotivation. These factors are intrinsic motivation - to know, intrinsic motivation - toward accomplishment, intrinsic motivation - to experience stimulation, extrinsic motivation - identified, extrinsic 
motivation - introjected, extrinsic motivation - external regulation and amotivation. Scores obtained from the sub factors range between 4 and 28 and there are no reverse scored items in the scale (Vallerand et al., 1992; Eymur \& Geban, 2011). The reliability analysis results of Turkish scale, the reliability coefficients of the sub factors range from .60 to .84 and the Cronbach's alpha values of the sub factors change between .60 and .84 (Eymur \& Geban, 2011).

\section{The Study Process Questionnaire}

The Study Process Questionnaire which was developed by Biggs et al., (2001) and adapted in Turkish by Yllmaz (2009) was used in this study.

The revised two-factor questionnaire contains 20 items and was developed in order to enable teachers to evaluate the learning environment in their classrooms. Each subfactor includes 10 items and all items in the questionnaire are positive. The maximum score that can be obtained from the questionnaire is 100 , while the minimum score is 20 (Biggs et al., 2001; Y1lmaz, 2009). In order to examine the validity of the Turkish scale, exploratory and confirmatory factor analyses were conducted. The Turkish form of the scale was administered to 400 university students for analysis of validity and reliability after examining and confirming equivalency between the English and Turkish versions. Cronbach's alpha was used to determine the reliability. The two subfactors of the questionnaire are the deep approach, which has a Cronbach's alpha coefficient of 0.79 , and the surface approach, which has a Cronbach's alpha coefficient of 0.73 (Y1lmaz, 2009).

\section{PROCEDURES}

Data were collected through the Academic Motivation Scale, The Study Process Questionnaire, and a Personal Information Form using face-to-face interviews with students (158 female and 8 male; 86 juniors and 80 seniors) studying early child education, at Georgia Southern University in the United States of America in the spring term of the 2013-2014 academic year and students (386 female and 150 male) studying at the Department of Primary School Education of Canakkale 18 Mart University in Turkey in the spring term of the 2012-2013 academic year.

Multiple regression, which is used to predict and relationship between two or more predictor variables and a criterion variable (Fraenkel \& Wallen, 2006), was used to analyze the data. Pearson correlation analysis was used for determining the relationship of GPA to scores obtained from the Academic Motivation Scale and theR-SPQ-2F; whereas multiple regression analysis was used for determining whether the Academic Motivation Scale and the RSPQ-2F together predicted GPA.

Grade point average (US): The GPA used for the US participants in this research corresponded to the average of all course grades in the $4^{\text {th }}$ and $5^{\text {th }}$ semesters among junior students and $6^{\text {th }}$ and $7^{\text {th }}$ semesters among senior students studying at Georgia Southern University's College of Education and Early Childhood Education Departments.

Grade point average (Turkey): The GPA for the Turkish participants was the average of the grades for all course grades in the $4^{\text {th }}$ and $5^{\text {th }}$ semesters among junior students and $6^{\text {th }}$ and $7^{\text {th }}$ semesters among senior students studying at Canakkale 18 Mart University's Primary School and Preschool Education Department.

Personal information form (used in both US and Turkey): Data on GPA were collected according to the students' self-report. The form consisted of questions about GPA, gender and year of study.

\section{RESULTS}

This section reports the results of the Pearson Product-Moment Correlation, which was carried out to determine whether there were significant correlations between early child education, classroom teaching and preschool education departments students' approaches to learning, academic motivation, and GPAs. Results of the 
multiple regression analysis, which was conducted for determining whether early child education students' approaches to learning and academic motivation together predict GPAs, are given.

Table 1. Minimum, Maximum, Mean And Standard Deviations Of GPA (Turkey And US Samples)

\begin{tabular}{lccccc}
\hline & N & Minimum & Maximum & Mean & Std. Deviation \\
\hline GPA (Turkey Sample) & 454 & 1.00 & 9.00 & 5.1586 & 1.31268 \\
GPA (US Sample) & 166 & 2.29 & 4.00 & 3.3315 & .41301 \\
\hline
\end{tabular}

Table 2. Correlation Of GPA To Academic Motivation And Approaches To Learning (US Sample)

\begin{tabular}{|c|c|c|c|c|c|c|c|c|c|c|c|c|}
\hline & 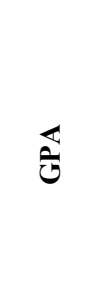 & 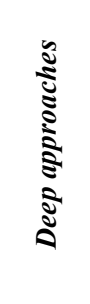 & 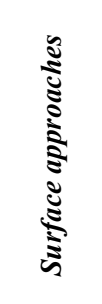 & 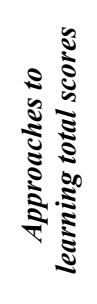 & 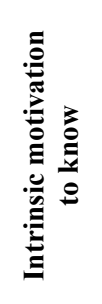 & 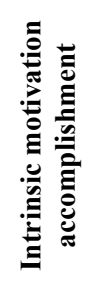 & 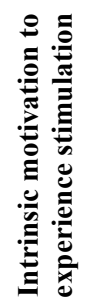 & 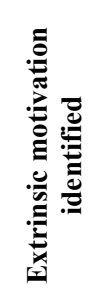 & 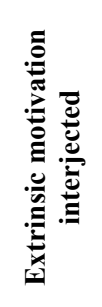 & 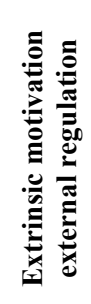 & 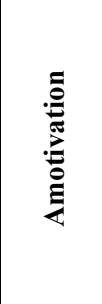 & 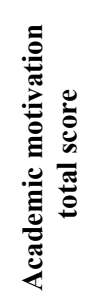 \\
\hline GPA & 1 & .029 & -.021 & .057 & .017 & .028 & -.045 & .053 & .046 & .019 & $-.169^{*}$ & -.017 \\
\hline Deep approaches & .029 & 1 & -.002 & $.474^{* *}$ & $.493^{* *}$ & $.499^{* *}$ & $.483^{* *}$ & $.228^{* *}$ & $.326^{* *}$ & .067 & .093 & $.491^{* *}$ \\
\hline Surface approaches & -.021 & -.002 & 1 & $.551^{* *}$ & $-.176^{*}$ & -.150 & -.070 & .077 & .034 & $.203^{* *}$ & $.328^{* *}$ & -.019 \\
\hline $\begin{array}{l}\text { Approaches to learning } \\
\text { total score }\end{array}$ & .057 & $.474^{* *}$ & $.551^{* *}$ & 1 & $.167^{*}$ & $.197^{*}$ & $.315^{* *}$ & $.286^{* *}$ & $.221^{* *}$ & $.212^{* *}$ & $.225^{* *}$ & $.315^{* *}$ \\
\hline $\begin{array}{l}\text { Intrinsic motivation to } \\
\text { know }\end{array}$ & .017 & $.493^{* *}$ & $-.176^{*}$ & $.167^{*}$ & 1 & $.722^{* *}$ & $.637^{* *}$ & $.395^{* *}$ & $.546^{* *}$ & $.250^{* *}$ & -.125 & $.719^{* *}$ \\
\hline $\begin{array}{l}\text { Intrinsic motivation } \\
\text { accomplishment }\end{array}$ & .028 & $.499^{* *}$ & -.150 & $.197^{*}$ & $.722^{* *}$ & 1 & $.627^{* *}$ & $.306^{* *}$ & $.570^{* *}$ & .124 & -.048 & $.716^{* *}$ \\
\hline $\begin{array}{l}\text { Intrinsic motivation to } \\
\text { experience stimulation }\end{array}$ & -.045 & $.483^{* *}$ & -.070 & $.315^{* *}$ & $.637^{* *}$ & $.627^{* *}$ & 1 & $.238^{* *}$ & $.450^{* *}$ & .135 & -.005 & $.648^{* *}$ \\
\hline $\begin{array}{l}\text { Extrinsic motivation } \\
\text { identified }\end{array}$ & .053 & $.228^{* *}$ & .077 & $.286^{* *}$ & $.395^{* *}$ & $.306^{* *}$ & $.238^{* *}$ & 1 & $.391^{* *}$ & $.371^{* *}$ & $-.224^{* *}$ & $.492^{* *}$ \\
\hline $\begin{array}{l}\text { Extrinsic motivation } \\
\text { introjected }\end{array}$ & .046 & $.326^{* *}$ & .034 & $.221^{* *}$ & $.546^{* *}$ & $.570^{* *}$ & $.450^{* *}$ & $.391^{* *}$ & 1 & $.360^{* *}$ & .016 & $.645^{* *}$ \\
\hline $\begin{array}{l}\text { Extrinsic motivation } \\
\text { external regulation }\end{array}$ & .019 & .067 & $.203^{* *}$ & $.212^{* *}$ & $.250^{* *}$ & .124 & .135 & $.371^{* *}$ & $.360^{* *}$ & 1 & .038 & $.432^{* *}$ \\
\hline Amotivation & $-.169^{*}$ & .093 & $.328^{* *}$ & $.225^{* *}$ & -.125 & -.048 & -.005 & $-.224^{* *}$ & .016 & .038 & 1 & .058 \\
\hline $\begin{array}{l}\text { Academic motivation } \\
\text { total score }\end{array}$ & -.017 & $.491^{* *}$ & -.019 & $.315^{* *}$ & $.719^{* *}$ & $.716^{* *}$ & $.648^{* *}$ & $.492^{* *}$ & $.645^{* *}$ & $.432^{* *}$ & .058 & 1 \\
\hline
\end{tabular}

According to Table 2, the GPAs of students who study in the US did not significantly correlate with academic motivation and approaches to learning. There was a significant correlation between academic motivation and approaches to learning $(p<.05)$. 
Table 3. Correlation Of GPA To Academic Motivation And Approaches To Learning (Turkish Sample)

\begin{tabular}{|c|c|c|c|c|c|c|c|c|c|c|c|c|}
\hline & 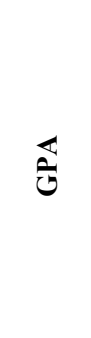 & 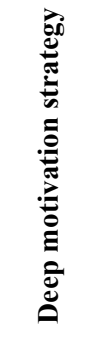 & 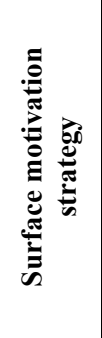 & 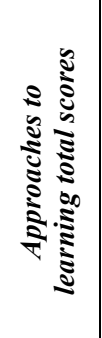 & 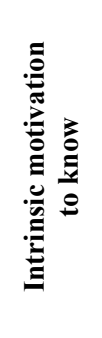 & 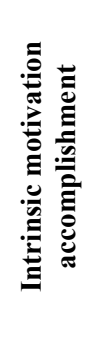 & 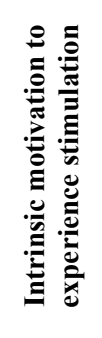 & 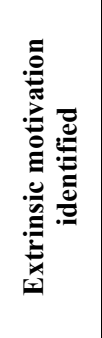 & 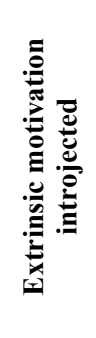 & 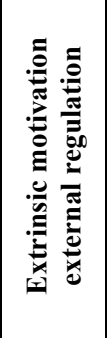 & 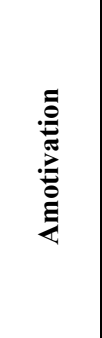 & 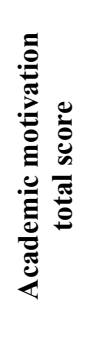 \\
\hline GPA & 1 & .034 & -.071 & -.013 & $.109^{*}$ & .049 & .041 & $.128^{* *}$ & .056 & .042 & $-.100^{*}$ & .071 \\
\hline Deep motivation strategy & .034 & 1 & .059 & $.555^{* *}$ & $.391^{* *}$ & $.394^{* *}$ & $.253^{* *}$ & $.252^{* *}$ & $.158^{* *}$ & $.112^{*}$ & -.011 & $.325^{* *}$ \\
\hline Surface motivation strategy & -.071 & .059 & 1 & $.571^{* *}$ & -.077 & -.040 & .054 & .020 & .028 & $.188^{* *}$ & $.211^{* *}$ & $.129^{* *}$ \\
\hline $\begin{array}{l}\text { Approaches to learning total } \\
\text { scores }\end{array}$ & -.013 & $.555^{* *}$ & $.571^{* *}$ & 1 & $.192^{* *}$ & $.243^{* *}$ & $.199^{* *}$ & $.232^{* *}$ & $.129^{* *}$ & $.125^{* *}$ & $.119^{*}$ & $.258^{* *}$ \\
\hline Intrinsic motivation to know & $.109^{*}$ & $.391^{* *}$ & -.077 & $.192^{* *}$ & 1 & $.490^{* *}$ & $.438^{* *}$ & $.476^{* *}$ & $.363^{* *}$ & $.324^{* *}$ & $-.157^{* *}$ & $.540^{* *}$ \\
\hline $\begin{array}{l}\text { Intrinsic motivation } \\
\text { accomplishment }\end{array}$ & .049 & $.394^{* *}$ & -.040 & $.243^{* *}$ & $.490^{* *}$ & 1 & $.419^{* *}$ & $.240^{* *}$ & $.468^{* *}$ & $.142^{* *}$ & .002 & $.553^{* *}$ \\
\hline $\begin{array}{l}\text { Intrinsic motivation to } \\
\text { experience stimulation }\end{array}$ & .041 & $.253^{* *}$ & .054 & $.199^{* *}$ & $.438^{* *}$ & $.419^{* *}$ & 1 & $.402^{* *}$ & $.292^{* *}$ & $.214^{* *}$ & $-.134^{* *}$ & $.542^{* *}$ \\
\hline $\begin{array}{l}\text { Extrinsic motivation } \\
\text { identified }\end{array}$ & $.128^{* *}$ & $.252^{* *}$ & .020 & $.232^{* *}$ & $.476^{* *}$ & $.240^{* *}$ & $.402^{* *}$ & 1 & $.251^{* *}$ & $.452^{* *}$ & $-.283^{* *}$ & $.538^{* *}$ \\
\hline $\begin{array}{l}\text { Extrinsic motivation } \\
\text { introjected }\end{array}$ & .056 & $.158^{* *}$ & .028 & $.129^{* *}$ & $.363^{* *}$ & $.468^{* *}$ & $.292^{* *}$ & $.251^{* *}$ & 1 & $.326^{* *}$ & $.099^{*}$ & $.571^{* *}$ \\
\hline $\begin{array}{l}\text { Extrinsic motivation external } \\
\text { regulation }\end{array}$ & .042 & $.112^{*}$ & $.188^{* *}$ & $.125^{* *}$ & $.324^{* *}$ & $.142^{* *}$ & $.214^{* *}$ & $.452^{* *}$ & $.326^{* *}$ & 1 & $-.139^{* *}$ & $.491^{* *}$ \\
\hline Amotivation & $-.100^{*}$ & -.011 & $.211^{* *}$ & $.119^{*}$ & $-.157^{* *}$ & .002 & $-.134^{* *}$ & $-.283^{* *}$ & $.099^{*}$ & $-.139^{* *}$ & 1 & $.095^{*}$ \\
\hline $\begin{array}{l}\text { Academic motivation total } \\
\text { score }\end{array}$ & .071 & $.325^{* *}$ & $.129^{* *}$ & $.258^{* *}$ & $.540^{* *}$ & $.553^{* *}$ & $.542^{* *}$ & $.538^{* *}$ & $.571^{* *}$ & $.491^{* *}$ & $.095^{*}$ & 1 \\
\hline
\end{tabular}

According to Table 3, the GPAs of students who studied in Turkey did not significantly correlate with academic motivation and approaches to learning. There was a significant correlation between academic motivation and approaches to learning $(p<.01)$.

Table 4. Results Of The Multiple Regression Analysis Regarding The Prediction Of GPAs By Academic Motivation And Approaches To Learning (Turkish Sample)

\begin{tabular}{|c|c|c|c|c|c|}
\hline & $\mathbf{B}$ & Standard Error B & B & $t$ & $p$ \\
\hline Constant & 4.764 & .542 & & 8.787 & 4.764 \\
\hline Deep motivation strategy & -.007 & .122 & -.004 & -.060 & -.007 \\
\hline Surface motivation strategy & -.088 & .121 & -.048 & -.729 & -.088 \\
\hline Approaches to learning total scores & -.012 & .202 & -.005 & -.060 & -.012 \\
\hline Intrinsic motivation to know & .099 & .111 & .057 & .900 & .099 \\
\hline Intrinsic motivation accomplishment & -.015 & .096 & -.010 & -.152 & -.015 \\
\hline Intrinsic motivation to experience stimulation & -.066 & .095 & -.042 & -.702 & -.066 \\
\hline Extrinsic motivation identified & .158 & .111 & .093 & 1.420 & .158 \\
\hline Extrinsic motivation introjected & .042 & .083 & .031 & .514 & .042 \\
\hline Extrinsic motivation external regulation & -.055 & .099 & -.033 & -.555 & -.055 \\
\hline Amotivation & -.090 & .070 & -.070 & -1.284 & -.090 \\
\hline Academic motivation total score & .076 & .198 & .032 & .383 & .076 \\
\hline
\end{tabular}


According to Table 4, academic motivation and approaches to learning total scores did not predict the GPAs of Turkish students $(p<.289)$.

Table 5. Results Of The Multiple Regression Analysis Regarding The Prediction Of GPAs By Academic Motivation And Approaches To Learning (US Sample)

\begin{tabular}{lccccc}
\hline & B & Standard Error B & B & t & p \\
\hline Constant & 3.246 & .311 & & 10.429 & .000 \\
Deep approaches & .012 & .069 & .018 & .170 & .952 \\
Surface approaches & -.034 & .071 & -.052 & -.482 & .467 \\
Approaches to learning total scores & .137 & .104 & .158 & 1.317 & .953 \\
Intrinsic motivation to know & .001 & .059 & .002 & .013 & .369 \\
Intrinsic motivation accomplishment & .029 & .057 & .069 & .513 & .880 \\
Intrinsic motivation to experience stimulation & -.051 & .044 & -.134 & -1.152 & .483 \\
Extrinsic motivation identified & -.019 & .071 & -.027 & -.269 & .156 \\
Extrinsic motivation introjected & .039 & .050 & .084 & .782 & .608 \\
Extrinsic motivation external regulation & .014 & .052 & .026 & .274 & .579 \\
Amotivation & -.134 & .064 & -.190 & -2.094 & .200 \\
Academic motivation total score & -.058 & .112 & -.082 & -.518 & .702 \\
\hline R & & & & &
\end{tabular}

$\mathrm{R}=.235, \mathrm{R}^{2}=.55$

$\mathrm{F}_{(11-154)}=.816 ; p<.624$

According to Table 5, academic motivation and approaches to learning total scores together did not predict the GPAs of US students $(p<.624)$.

\section{CONCLUSION AND DISCUSSION}

My study findings indicate that academic motivation and approaches to learning are not significantly correlated to Turkish and US students' GPAs. Contrary to our results, a significant relationship between motivation and academic achievement has been reported in the literature (Amrai, Motlagh, Zalani, \& Parhon, 2011; Özder \& Motorcan, 2013). Heikkilä and Lonka (2006) found a low positive correlation between academic average and the deep learning approach. Diseth (2002) found a negative correlation between the surface approach and the academic achievement. Diseth (2007) determined a positive correlation between exam grades and the deep approach. Ekinci (2009) found a significant positive correlation between students' level of achievement and deep and strategic learning approach scores and a significant negative correlation between surface learning approach scores and achievement. Lavender (2005) found a significant correlation between extrinsic motivation external regulation, which is one of the subfactors of academic motivation scale, and academic achievement. Cokley, Bernard, Cunningham, and Motoike (2001) found significant correlations between GPA and amotivation, intrinsic motivation to know, intrinsic motivation to achieve, and intrinsic motivation to experience stimulation subfactors. Robinson (2003) detected a positive correlation between intrinsic motivation to achieve and achievement and a negative correlation between amotivation and achievement.

This study found that academic motivation and approaches to learning did not significantly correlate with GPA in Turkish and US sample. It is assumed that the similarity among students' GPAs is the reason for not finding a significant correlation between GPA and academic motivation and approaches to learning. Another reason for not finding a significant correlation is that there were a large number of uncontrolled factors that possibly affect GPA. Finding similar results in two different cultures indicate that students' GPAs may also be related to variables such as intelligence, age, educational level of parents, self-efficacy, learning styles and cognitive skills.

Academic motivation and approaches to learning together did not significantly predict GPA in Turkish and US students. Contrary to our findings, Komarraju, Karau, and Schmeck (2009) determined that amotivation and the intrinsic motivation to accomplish were the best predictors of achievement. Diseth (2003) found that approaches to learning predicted academic achievement. And according to Choy, O'Grady, and Rotgans (2012), students' approach to learning was a weak predictor of academic achievement. Burton and Sztaroszta (2007) found that the deep learning approach was not a positive predictor of academic achievement. Diseth, Pallesen, Brunborg, and Larsen (2010) indicated that approach to learning was an independent predictor of test performance. Salamonson et al. (2013) found that surface and deep approaches to learning were important predictors of academic performance. 
Lizzio, Wilson, and Simons (2002) determined that the surface approach to learning was a better predictor of GPAs than deep approaches to learning in college students. Komarraju et al. (2009) determined that the best predictors of achievement were amotivation and intrinsic motivation to accomplish.

I realised that many factors affect students' GPAs in this study. It was assumed that factors including intelligence, cognitive skills, attitudes, having willingly chosen their academic department and major, thinking skills, studying habits, learning strategies, interest, attention, and self-efficacy possibly affect GPAs. In addition, the limited range of students' GPAs may be the reason for not being able to predict students' GPAs from academic motivation and approaches to learning.

\section{AUTHOR INFORMATION}

Barış Çetin, Ph.D., Department of Elementary Education, Canakkale 18 Mart University Turkey. For information about the work described in this article correspondence should be addressed to: Barış Çetin, Ph.D. Canakkale 18 Mart University, Department of Elementary Education, Canakkale, Turkey, 17100. Email: bcetin@comu.edu.tr

\section{REFERENCES}

Amrai, K., Motlagh, S.E., Zalani, H.A., \& Parhon, H. (2011).The relationship between academic motivation and academic achievement students. Procedia-Social and Behavioral Sciences, 15, 399-402.

Biggs, J.B. (1999a). Teaching for quality learning at university. Buckingham, UK: Open University Press.

Biggs, J. (1999b). What the student does: Teaching for enhanced learning. Higher Education Research \& Development, 31(1), 39-55.

Biggs, J. (2012). Enhancing learning through constructive alignment. In J. R. Kirby \& M. J. Lawson (Eds.), Enhancing the quality of learning: Dispositions, instruction, and learning processes (pp.117-136). Cambridge, UK: Cambridge University Press.

Biggs, J., Kember, D., \& Leung, D.Y.P. (2001). The Revised Two-factor Study Process Questionnaire: R-SPQ-2F. British Journal of Educational Psychology,71(1), 133-149.

Bowden, J., \& Marton, F. (1998).The university of learning beyond quality and competence. London, UK: Routledge Falmer Taylor \& Francis Group.

Burton, Lorelle J. \& Sztaroszta, J. (2007) The relationship among conceptions of knowledge, approaches to learning, personality, and academic success. In: 42nd Australian Psychological Society Annual Conference, Brisbane, Australia.

Choy, J. L. F., O'Grady, G., \& Rotgans, J. I. (2012). Is the Study Process Questionnaire (SPQ) a good predictor of academic achievement? Examining the mediating role of achievement-related classroom behaviours. Instructional Science, 40, 159-172. DOI: 10.1007/s11251-011-9171-8

Cokley, K.O., Bernard, N., Cunningham, D., \& Motoike, J. (2001). A psychometric investigation of the Academic Motivation Scale using a United States sample. Measurement and Evaluation in Counseling and Development, 34,109-119.

Deci, E. L., \& Ryan, R. M. (1985). Intrinsic motivation and self-determination in human behavior. New York, NY: Plenum Press.

Deci, E. L., \& Ryan, R. M. (1995). Human autonomy: The basis for true self-esteem. In M.Kernis (Ed.), Efficacy, agency, and self-esteem (pp. 31-49). New York, NY: Prenium.

Deci, E. L., \& Ryan, R. M. (2002). An overview of self-determination theory: Organismic-dialectical perspective. In E. L. Deci \& R. M. Ryan (Eds.), Handbook of self-determination research (pp. 3-33). Rochester, NY: The University of Rochester Press.

Deci, E. L., \& Ryan, R. M. (2008). Self-determination theory: A macrotheory of human motivation, development and health. Canadian Psychology, 49, 182-185. Retrieved from http://selfdeterminationtheory.org/faculty?id=86

Diseth, A. (2002). The relationship between intelligence, approaches to learning and academic achievement. Scandinavian Journal of Educational Research, 46(2), 219-230. DOI: 10.1080/00313830220142218

Diseth, A. (2003). Personality and approaches to learning as predictors of academic achievement. European Journal of Personality, 17, 143-155. DOI: 10.1002/per.469 
Diseth, A. (2007). Students' evaluation of teaching, approaches to learning, and academic achievement. Scandinavian Journal of Educational Research, 51( 2), 185-204. DOI: 10.1080/00313830701191654

Diseth, A., Pallesen, S., Brunborg, G.S., \&Larsen, S.(2010). Academic achievement among first semester undergraduate psychology students: The role of course experience, effort, motives and learning strategies. Higher Education, 59, 335-352. DOI: 10.1007/s10734-009-9251-8

Ekinci, N. (2009). Learning approaches of university students. Education and Science, 34(151).

Entwistle, N. (2005). Learning outcomes and ways of thinking across contrasting disciplines and settings in higher education. The Curriculum Journal, 16(1), 67-82. DOI: 10.1080/0958517042000336818

Entwistle, N. (2009). Universities into the $21^{\text {st }}$ century, teaching for understanding at university: Deep approaches and distinctive ways of thinking. New York, NY: Palgrave MacMillan.

Entwistle, N., \& McCune V. (2004). The conceptual bases of study strategy inventories. Educational Psychology Review, 16(4),325-345.

Entwistle, N. , \& Smith, C. (2002). Personal understanding and target understanding: Mapping influences on the outcomes of learning. British Journal of Educational Psychology, 72, 321-342.

Eymur, G., \& Geban, O. (2011). Kimya öğretmeni adaylarının motivasyon ve akademik basarilari. Eğitim ve Bilim, $36(161)$.

Fraenkel, J.R., \& Wallen, N.E. (2006). How to design and evaluate research in education. New York, NY: McGraw Hill.

Gay, L.R., Mills, G.E., \&Airasian, P. (2009). Educational research competencies for analysis and applications. New Jersey Columbus, Ohio: Pearson Education.

Heikkilä, A., \& ve Lonka, K. (2006). Studying in higher education: students' approaches to learning, self-regulation, and cognitive strategies. Studies in Higher Education, 31(1),99-117.

Komarraju, M., Karau, S. J., \& Schmeck, R. R.(2009). Role of the big five personality traits in predicting college students' academic motivation and achievement. Learning and Individual Differences, 19, 47-52.

Lizzio, A. , Wilson, K., \& Simons, R. (2002). University students' perceptions of the learning environment and academic outcomes: Implications for theory and practice. Studies in Higher Education, 27, 27-52. DOI: $10.1080 / 03075070120099359$

Lavender, M.M.(2005). A comparison of academic motivation of academically prepared and academically unprepared community college students (Unpublished doctoral dissertation). The Florida State University College of Education, Gainesville, FL, USA.

Marton, F., \& Säljö, R. (1976).On qualitative differences in learning-Outcome and process.British Journal of Educational Psychology, 46, 4-11. DOI: 10.1111/j.2044-8279.1976.tb02980.x

Marton, F.,\& Booth, S. (2009). Learning and awareness. New York, NY: Routledge Taylor\& Francis Group.

Özder, H., \& Motorcan, A. (2013). An analysis of teacher candidates' academic motivation levels with respect to several variables. British Journal of Arts and Social Sciences, 15(1), 42-53.

Ratelle, C. F., Guay, F., Vallerand, R. J., Larose, S., \& Sene'cal, C. (2007). Autonomous, controlled, and amotivated types of academic motivation: A person-oriented analysis. Journal of Educational Psychology, 99(4), 734746.

Robinson, N.M. (2003). Academic motivation and its relationship to personality variables and achievement (Unpublished doctoral dissertation). Southern Illinois University, Carbondale, IL, USA.

Salamonson, Y., Roslyn Weaver, R., Chang, S., Koch, J., Bhathal, R., Khoo, C., \& Wilson, I.(2013). Learning approaches as predictors of academic performance in first year health and science students. Nurse Education Today,33, 729-733.

Skinner, B. F. (1953). Science and human behavior. New York, NY: Macmillan.

Vallerand, R. J., Pelletier, L. G., Blais, M. R, Brière, N. M., Senécal, C., \& Vallières, E. F. (1992). The Academic Motivation Scale: A measure of intrinsic, extrinsic, and amotivation in education. Educational and Psychological Measurement, 52, 1003-1017.

Vallerand, R.J., \& Bissonnette, R. (1992). Intrinsic, extrinsic, and amotivational styles as predictors of behavior: A prospective study. Journal of Personality, 60(3), 599-620.

Vansteenkiste, M., Lens, W., \& Deci, E. L. (2006). Intrinsic versus extrinsic goal contents in self-determination theory: Another look at the quality of academic motivation. Educational Psychologist, 41(1), 19-31.

Williams, G. C., \& Deci, E. L.(1996). Internalization of biopsychosocial values by medical students: A test of selfdetermination theory. Journal of Personality and Social Psychology, 70(4), 767-779. 
Yılmaz, M.B. (2009). Karma ogrenme ortamındaki universite öğrencilerinin ogrenme yaklaşımlarına göre ders basarilarinin, derse devamlarının, web materyalini kullanma davranışlarının ve ortama yönelik memnuniyetlerinin değerlendirilmesi(Unpublished doctoral dissertation). Y1ldız Teknik University,Istanbul, Turkey.

Zimmerman, B.J. (2012). Goal setting: A key proactive source of academic self-regulation. In D. H. Schunk, \&B. J. Zimmerman (Eds.), Motivation and self-regulated learning: Theory, research, and applications (pp.267295). New York, NY: Routledge Taylor \&Francis Group. 